\title{
Perspektif Hos Tjokroaminoto Tentang Pendidikan Islam
}

\author{
Endan Hamdan Ridwan \\ Sekolah Tinggi Ilmu Tarbiyah (STIT) Al-Azami Cianjur, Indonesia \\ hamdanridwan890@gmail.com
}

DOI: https://doi.org/10.52593/pdg.01.1.02

Naskah diterima: 14 Februari 2020, direvisi: 7 Mei 2020, disetujui: 21 Juni 2020

\begin{abstract}
Abstraksi
Penelitian ini mencoba untuk mendeskripsikan pemikiran HOS Tjokroaminoto tentang Pendidikan Islam, penelitian ini merupakan penelitian dokumentasi perpustkaan (library research) dengan menggunakan pendekatan kualitatif naratif. Sedangkan metode yang digunakan adalah deskriptif kualitatif dengan studi tokoh. Kajian studi tokoh adalah pengkajian secara sistematis terhadap pemikiran atau gagasan seorang pemikir muslim. Hasil penelitiannya adalah 1) Pendidikan karakter secara Islami benar-benar harus diterapkan baik di sekolah formil ataupun lingkungan keluarga, untuk membentengi diri dari dekadensi zaman Jahiliyah Modern. Karakter pendidikan Islam harus melalui :2) Pendidikan Islam harus berdasarkan Al-Quran dan Hadits.
\end{abstract}

Kata Kunci : HOS Tjokroaminto, Pendidikan Islam, Karakter, Sekolah, Keluarga

\section{A. Pendahuluan}

HOS Tjokroaminoto dikenal sebagai seorang ulama, politikus, ekonom Islam yang sangat berpengaruh di abad 20. Ahmad (2010) berpandangan bahwa dan berdasar pada dua prinsip yaitu kedermawanan Islam dan Persaudaraan Islam. Pada konsepsi ini diperlihatkan kearifan Islam dalam menjawab berbagai masalah sosial ekonomi. Gagasan untuk saling tolong-menolong dan bersatu membangun perekonomian yang mengacu pada dasar-dasar syariat Islam, menjadi sebuah ide segar yang mampu menjawab banyak masalah sosial maupun ekonomi. Manifestasi dari pemikirannya tersebut tergambar jelas saat bergabung bersama Sarekat Dagang Islam (SDI) dan berkembang menjadi Sarekat Islam (SI) yang dipimpinnya.

Peran Tjokroaminoto selama menjadi anggota SDI (Sarekat Dagang Islam), yang akhirnya beliau rubah menjadi SI (Sarekat Islam) pada 1912, menjadi sebuah gambaran nyata bagaimana Tjokroaminoto adalah seorang pemerhati pendidikan, ilmuwan, sekaligus seorang praktisi ekonomi. Ketika Tjokroaminoto melihat adanya potensi intelektual dalam badan SDI kala itu, dan di sisi lain banyak kesenjangan dan penderitaan rakyat luas yang notabene bukan kaum pedagang, maka tergeraklah ide Tjokroaminoto untuk memperluas cakupan bidang garapan SDI agar membawa kemaslahatan bagi ummat. SI kemudian berkembang pesat dan menjadi satu saka guru kebangkitan nasional 
kala itu. Tujuan SI adalah membangun persaudaraan, persahabatan dan tolong-menolong diantara muslim dan mengembangkan perekonomian rakyat. ${ }^{1}$

Permasalahan sosial yang dihadapi zaman dimana Tjokroaminoto hidup adalah diskriminasi ilmu pengetahuan dan pendidikan Islam. Sama halnya dengan era dewasa ini, bahwa perguruan tinggi milik negara memberikan biaya sekolah yang berbeda untuk masyarakatnya dan masyarakat asing. Contoh kasus pada salah satu perguruan tinggi terkemuka di Indonesia, biaya perkuliahan untuk mahasiswa Indonesia berkisar antara 13 juta rupiah per semester tetapi untuk mahasiswa asing berkisar sekitar 10 juta rupiah/ 1000 dollar per semester. Scherer (1985) meyakinkan bahwa diskirimasi pengetahuan telah terjadi dalam perjalanan sejarah pendidikan Indonesia terutama di era pergerakan nasional. Dimana lembaga pendidikan yang dibentuk pemerintah kolonial Hindia Belanda memberikan perbedaan tentang biaya sekolah untuk anak-anak eropa dan pribumi. Lebih lanjut Scherer (1985:44) menambahkan bahwa biaya sekolah anak-anak pribumi dua kali lipat dari anak-anak eropa sebesar 15 gulden perbulan sehingga hanya anak-anak pribumi yang ningrat dan kaya raya sajalah yang mampu sekolah di lembaga pendidikan pemerintah. Masalah utama masyarakat adalah buta huruf dan buta angka sehingga membuat Tjokroaminoto nantinya tergerak untuk menyinari dunia pendidikan Indonesia dengan pancaran pendidikan Islam. ${ }^{2}$

Muljono \& Kutoyo (1985:16) mengungkapkan bahwa dalam bidang perekonomian, orang-orang mempunyai kedudukan yang makin kokoh sehingga pemerintah Hindia Belanda yang pada masa itu memerlukan banyak sekali uang, menyewakan tanah-tanah yang luas pada orang-orang yang nantinya disebut sebagai cukong tanah ini. Hal ini diperparah para bangsawan pribumipun ikut menyewakan tanah mereka yang berakibat banyak dari mereka yang jatuh miskin. Dengan demikian semakin sengsaralah rakyat bumiputera saat itu. Jangankan untuk mengenyam pendidikan formal yang layak, untuk sekedar menghirup udara kebebasan saja tidak puas. ${ }^{3}$

Ketika Tjokroaminoto lahir di Desa Bakur, Madiun, Jawa Timur, 16 Agustus 1882, masyarakat Indonesia adalah masyarakat jajahan yang dikuasai oleh Pemerintah Hindia Belanda. Pemerintah ini tidak bertanggung jawab pada rakyat tetapi hanya sebagai badan penyelenggara yang bekerja di bawah dan atas tanggung jawab pemerintah Belanda. Di tanah air ini hanya diadakan wali negara yang menyerahkan segala tugas dan kewajibannya pada Departemen Pusat (Department van Algemeen Bestuur). Di daerahdaerah terdapat gouverneur yang menngepalai provincie, resident yang mengepalai residentie, dan assistant resident yang mengepalai afdelling. Semua kepala daerah tersebut orang Belanda dan orang bumiputera hanya menjadi bupati yang diawasi oleh controleur yang notabene orang Belanda. ${ }^{4}$

\footnotetext{
${ }^{1}$ Ahmad, H, 2010, Ekonomi dalam Pandangan H.O.S. Tjokroaminoto. Diakses tanggal 12 Juni 2012 darihttp://harisahmad.blogspot.com/2010/05/ekonomi-dalampandangan-hos.html

${ }^{2}$ Scherer, SP, 1985, Keselarasan \& Kejanggalan:Pemikiran-Pemikiran Priayi Nasionalis Jawa Awal Abad $X X$, Jakarta, Sinar Harapan

${ }^{3}$ Muljono \& S. Kutoyo,1985, Haji Saman Hudi, Jakarta, Depdikbud, 5.

${ }^{4}$ Ibid, 5
} 
Pada masa itu banyak terjadi diskriminasi antara orang Belanda, Cina, dan pribumi dalam segala aspek kehidupan. Bangsa kita saat itu disebut sebagai inlanders atau pribumi yang memiliki kedudukan sangat rendah sekali. Hal ini kecuali pribumi yang memiliki darah biru yang sedikit berada pada posisi yang baik. Sikap diskriminatif bahkan terjadi dalam kehidupan sehari-hari, mengungkapkan bahwa terjadi pembedaan antara pribumi dan Belanda dalam hal karcis kereta api, ada beberapa karcis berwarna, karcis putih untuk golongan orang Belanda dan Cina dan karcis hijau untuk golongan pribumi yang ditambahkan tulisan voo inlanders yang berarti orang pribumi. Sikap diskriminatif ini juga terjadi dalam tempat pemandian yang biasa didatangi orang Belanda dan orang asing lainnya terdapat tulisan verboden voor inlanders yang berarti dilarang masuk bagi orang pribumi. Sikap diskriminatif ini juga terdapat dalam aspek pendidikan formal, bagi orang pribumi yang ingin masuk sekolah Belanda seperti HBS atau ELC harus memenuhi syarat yang berat yakni penghasilan orang tua dia atas 150 gulden dan bahasa yang dipakai adalah Bahasa Belanda. Hal ini berbeda dengan Tjokroaminoto yang masih seorang keturunan bangsawan yang bergelar Raden Mas \& berhasil mengecap ilmu pengetahuan di OSVIA (sekolah untuk calon pegawai bumiputera). ${ }^{5}$

Pada awal abad ke-20 terjadi peristiwa penting dalam dunia Islam yang sedikit banyak juga berpengaruh pada pikiran Tjokroaminoto yakni gagasan ukhuwah islamiyah atau pan-islamisme. Hal inilah yang kemudian menginspirasinya dalam menemukan cara bagaimana menyejahterakan umat yakni dengan menggalang persatuan umat islam di seluruh daerah Nusantara. Dia kemudian menjadi ketua Sarekat Islam yang berdiri karena berlatar belakang hegemoni dari kaum Cina atas perekonomian Jawa. Islam jugalah yang kemudian menjadi ideologi penting dalam hidupnya termasuk nantinya dia menanamkan nafas islam dalam sekolah-sekolah SI yang dibangunnya.

Tjokroaminoto juga terinspirasi oleh seorang tokoh timur tengah pada dasawarsa kedua abad ke-20 yakni Mustafa Kemal Pasha. Isawati (2012:99) mendeskripsikan bahwa Mustafa kemal dapat merubah Turki yang sakit menjadi Turki yang modern melalui Kemalisme atau filsafat kemal yang menganjurkan bahwa kebahagiaan terletak dalam kemerdekaan hidup dan suatu bangsa tidak akan bahagia jika tidak merdeka. Seperti halnya Mustafa Kemal, Tjokroaminoto dalam membangun umatnya juga memakai tangan besi. Dia cenderung menggunakan segala cara untuk memenuhi ambisinya termasuk ketika menjungkalkan Samanhoedi. ${ }^{6}$

Berangkat dari sejarah spekulatif bahwa dengan belajar sejarah yang mengkaji masa lalu untuk menemukan pola-pola yang umum maka dengan pola tersebut digunakan untuk memprediksi apa yang terjadi ke depannya. Tulisan ini diharapkan dapat menjadi salah satu alternatif solusi dalam menyelesaikan permasalahan pendidikan dan sosial bangsa ini melalui gagasan seorang muslim taat bernama Tjokroaminoto. Hal itu

\footnotetext{
${ }^{5}$ Soebagijo, 1985, Harsono Tjokroaminoto : Mengikuti Jejak Perjuangan Sang Ayah, Jakarta, Gunung Agung, 1

${ }^{6}$ Tempo. 2011, TjokroaminotoGuru Para Pendiri Bangsa, Jakarta, Kepustakaan Populer Gramedia, 77
} 
membuat tulisan ini berfokus pada bagaimana latar belakang pemikiran pendidikan Tjokroaminoto, bagaimana pemikiran pendidikan Tjokroaminoto, bagaimana pemikirannya menginspirasi tokoh bangsa nantinya, dan apa yang dapat diungkapkan sebagai sarana solutif bagi permasalahan bangsa ini jika mengkaji gagasan dari Tjokroaminoto.

\section{B. Teori / Konsep}

\section{HOS Tjokroaminoto; Pendidikan dan Pemikirannya}

Nama lengkap beliau adalah RadenHaji Oemar Said Tjokroaminoto. dilahirkan di Bakur, sebuah desa yang sunyi pada tanggal 16 Agustus 1982 bertepatan dengan tahun meletusnya gunung Krakatau di Banten. Peristiwa ini sering dikiaskan oleh orang Jawa bahwa gunung meletus itu akan banyak menimbulkan perubahan terhadap alam di sekelilingnya. Peristiwa ini pula yang kelak dikaitkan dengan meledaknya tuntutan H.O.S Tjokroaminoto terhadap pemerintah kolonial Belanda ketika ia menjadi pemimpin Sarekat Islam. Diantara pendidikannya adalah di Olpayding School Foor Indandishe Ambegtenaren (OSVIA) di kota Magelang lulus tahun 1902. Yang kemudian melanjutkan di Burgerlijke Avondschool (dari tahun 1907 hingga 1910). Dalam perjalanan karir beliau diantaranya pernah bekerja sebagai kuli juru tulis Patih di Ngawi selama kurang lebih 3 tahun. Setelah itu merantau ke Surabaya untuk bekerja pada sebuah firma Kooy \& Co. ${ }^{7}$

HOS Tjokroaminoto berpendapat:

"Di kota - kota besar nampak pula kerusakan moral (budi pekerti) bangsa kita. Bukan saja pelacuran yang merajalela dari kota-kota sampai ke desa-desa, tetapi yang di katakan kaum terpelajar, pemuda-pemudi tak ada lagi pergaulan dalam hidupnya, pergaulan yang merdeka, pergaulan yang mempengaruhi pada kesesatan.Sumber-sumber pelacuran telah menjadi pergaulan yang modern.Kemajuan yang mencontoh dunia barat yang memang sudah rusak, rusak budi pekerti dan rohaninya. Tak ada lagi kendali dalam jiwa yang dapat menahan hawa nafsu inilah yang dikatakan "Jahiliah Modern"8

Inilah kalimat kegelisahan Pak Tjokro.Zaman ini moral dan budi pekerti hanya sebagai harapan belaka saja, banyak anak muda rusak moralnya. Sebab pendidikanIslam zaman ini tidak di latih mengendalikan dirinya, tidak dilatih mengendalikan jiwanya. Sebagian besar, rupa pendidikan saat ini hanya dilatih untuk mewujudkan keinginannnya saja. Sebagai contoh anak sejak TK, pertanyaan yang selalu di tanyakan oleh gurunya adalah, "Anak-anak kalau sudah besar nanti mau jadi apa?"

Sejak kecil sudah di latih melampiaskan hasratnya, tidak keliru hanya saja perlu di imbangi dengan ajaran mengendalikan diri dan tanpa bisa mengendalikan

\footnotetext{
${ }^{7}$ Amels, H.O.S Tjokroaminoto Jilid 1 (Djakarta:Bulan Bintang,1952),50

${ }^{8}$ Tjokroaminoto, H. 1983, Menelusuri Jejak Ayahku, Penerbitan Sejarah Lisan No. 2. Jakarta, Arsip Nasional Republik Indonesia
} 
diri, ini bisa merusak mental. Sejak dini anak - anak sudah di cekoki hal-hal yang bersifat angan-angan tanpa ada pengendalian diri.

\section{PendidikanKarakter}

Jadi berpuluh-puluh tahun yang lalu, pak Tjokro sudah berbicara perihal pentingnya pendidikan karakter. Pendidikan karakter inilah yang membikin bangsa maju dan beradab, tidak memandang sesuatu hanya bersifat materi saja.Maka dari itu, pak Tjokro dengan kalimat yang indah menjabarkan betapa pendidikan Karakter ini harus di miliki oleh anak- anak Indonesia.

HOS Tjokroaminoto menjabarkan:

"Kalau ada orang Islam mendirikan Sekolah (Madrasah) tinggi, pertengahan atau rendah, dengan cuma memberikan ajaran kepandaian akal saja, tetapi di dalam hatinya anak-anak tidak di tanamkan benih kemerdekaan dan benih demokrasi, yang menjadi tanda kebesaran dan tanda perbedaan umat Islam besar pada zaman dulu itu. Dan didalam hatinya anak-anak tidak pula di tanamkan benihya keberanian yang luhur, keihlasan hati, kesetiaan dan kecintaan pada barang yang benar yang telah menjadi tabi'at pergaulan hidup Islam pada zaman dulu dan murid-murid juga tidak di beri pengajaran yang mendidik kebatinan yang halus, keutamaan budi dan perangai yang benar yang dulu telah menjadikan orang Arab penduduk lautan pasir menjadi bangsa tuan yang halus 'adat lembaganya' dan menjadi tukang menamam keadaban dan kesopanan, juga di dalam hatinya murid-murid tidak di tanamkan bijinya penghidupan yang shaleh yang sederhana sebagaimana yang dulu menjadikan mahsur ummat Islam. Sekolah-sekolah yang hanya memberikan kepandaian yang "dingin" tidak hidup dan akhirnya hanya akan menuntun pada matrealisme saja. Sekolah-sekolah yang dimikian itu lebih baik tidak ada saja"

Tidak ada gunanya, jika anak-anak hanya di ajari kepandaian yang dingin dan hanya untuk dirinya saja. Bersikap apatis terhadap lingkungan sekitar, tidak melek masalah yang terjadi, hidup hanya untuk dirinya saja.Miskin daya cipta dan ujung-ujungnya menjadi intelektual tradisional.Meskipun dengan berbagai macam label sekolah unggulan, sekolah bertarap internasional. Tapi tidak diajarkan pendidikan karakter.

Semakin hari, pendidikan hanya bersifat matrealistis, besok anak ini jadi apa, biar dia kaya dia harus sekolah apa, biar di karir sukses harus lewat jalur apa.(Manpan Drajat, 2015) Pikiran-pikiran semacam itu selalu muncul dalam benak orang tua tanpa di bentengi dengan pengendalian diri.Harus di akui memang sebagian orang tua pasti memikirkan hal seperti itu.Inilah bentuk pendidikan zaman ini segalanya hanya bersifat materi.Ini sejak dulu sudah di ingatkan oleh Pak Tjokro "Sekolah-sekolah yang hanya memberikan kepandaian yang "dingin" tidak

\footnotetext{
${ }^{9}$ Tjokroaminoto, H. 1983, Menelusuri Jejak Ayahku, Penerbitan Sejarah Lisan No.2. Jakarta, Arsip Nasional Republik Indonesia
} 
hidup dan akhirnya hanya akan menuntun pada matrealisme saja.Sekolah-sekolah yang dimikian itu lebih baik tidak ada saja" Jadi inilah tugas guru dan orang tua, memberi anak didik kita bekal yang mempuni, bukan hanya kepandaian yang menuntun pada yangbersifat materi tapi juga pendidikan karakter yang mampu merubah generasi bangsa. ${ }^{10}$

HOS Tjokroaminoto berpendapat: "Anak-anakku semuanya, kalau kamu sudah mendapatkan pendidikan Islam dan kamu sudah pada dewasa, jika ditakdirkan Allah SWT, kamu di jadikan orang Tani, tentu kamu bisa mengerjakan pertanian secara Islam, kalau kamu di takdirkan jadi Saudagar, jadilah Saudagar secara Islam, kalau kamu di takdirkan jadi Prajurit, jadilah Prajurit dengan cara Islam dan kalau kamu ditakdirkan jadi Senopati, Jadilah Senopati menurut ajaran Islam. Hingga dunia di atur sesuai asas - asas Islam "11

Jadi kalau dunia ini ingin diatur secara Islam, berbau Islam caranya sederhana saja, setiap Muslim jalankan setiap profesi yang kalian geluti secara Islam. Tidak perlu koar-koar memaksa orang dengan kekerasan pada orang lain yang di anggap tidak sesuai dengan kelompoknya. Jadi harus sadar diri terlebih dahulu, apakah cara yang kita tempuh dan jalankan apakah sudah sesuai dengan cara Islam apa belum.

\section{Metode Penelitian}

Pendekatan penelitian yang digunakan oleh peneliti adalah pendekatan kualitatif naratif yaitu sebuah pendekatan penelitian yang menggunakan diskripsi-deskripsi baik secara lisan maupun tulisan. Sebagaimana Bogdan dan Taylor mendefenisikan penelitian kualitatif sebagai prosedur penelitian yang menghasilkan data deskriptif berupa kata-kata tertulis atau lisan dari orang-orang dan pelaku yang dapat diamati, pendekatan ini diarahkan pada latar dan individu secara holistik (utuh). ${ }^{12}$

Pendekatan ini digunakan dan dipilih oleh peneliti karena peneliti ingin mendiskripsikan hasil penelitiannya dalam bentuk kata-kata bukan angka dan ingin mengkaji lebih mendalam tentang Presfektif H.O.S Tjokroaminoto tentang Pendidikan Islam.

Jenis penelitian ini adalah bersifat deskriptif kualitatif dengan studi tokoh. Kajian studi tokoh adalah pengkajian secara sistematis terhadap pemikiran atau gagasan seorang pemikir muslim, keseluruhannya atau sebagiannya. Pengkajian meliputi pendahuluan internal, eksternal, perkembangan pemikiran, hal-hal yang diperhatikan dan kurang diperhatikan, kekuatan dan kelemahan pemikiran tokoh, serta kontribusinya bagi zamannya dan masa sesudahnya. ${ }^{13}$

\footnotetext{
${ }^{10}$ Mukti, D. 2010. Tjokroaminoto dan PendidikanMoeslim Nationaal, Onderwijs, Diakses tanggal 17 Juni 2012, dari http:/tjokroaminoto, wordpress.com/ Onderwijs.

${ }^{11}$ Ibid, 17 Juni 2012

${ }^{12}$ Lexy J. Moleong, 2005, Metodologi Penelitian kualitatif, Bandung, Remaja Rosdakarya), 4.

${ }^{13}$ Syahrin Harahap, 2011, Metodologi Studi Tokoh Pemikiran Islam, Jakarta, Prenada, 16.
} 
Anton Baker sebagaimana yang dikutip oleh Syahrin Harahap secara jelas memasukkan studi tokoh sebagai bagian dari penelitian sejarah, serta memberikan langkah-langkah pelaksanaannya.

Sumber data dalam proses penelitian ini adalah menggunakan dokumentasi. Menurut Sugiyono, suatu penelitian bila dilihat dari sumber data yang digunakan, terdapat dua macam, yaitu: (1) sumber data primer, yaitu sumber data yang langsung memberikan data kepada peneliti. Adapun data primer dalam penelitian ini adalah karyakarya yang ditulis langsung oleh tokoh yang diteliti. Dalam hal ini adalah H.O.S Tjokroaminoto, (2) sumber data sekunder, yaitu sumber data yang tidak langsung memberikan data kepada peneliti, misalnya melalui orang lain atau melalui dokumen, yaitu karya-karya yang secara intelektual tidak terjadi kontak, tetapi ada kesamaan tematema pemikiran yang dikembangkannya. ${ }^{14}$

\section{Pemikiran Pendidikan Islam HOS Tjokroaminoto}

\section{Konsep dan Corak Pemikirannya}

Sebelumnya, Cokroaminoto cenderung lebih dikenal sebagai tokoh politik dibandingkan sebagai tokoh pendidikan karena kiprahnya dalam Organisasi Syarikat Islam (SI). Terlepas dari itu semua, mari kita menelaah beberapa pemikiran pendidikan HOS Tjokroaminoto sebagai berikut.

a. Pendidikan Islam harus berdasarkan Al-Quran dan Hadits.

Menurut HOS Tjokroaminoto ilmu harus diperoleh dengan akal, tetapi tidak boleh dipisahkan dari pendidikan budi pekerti dan pendidikan rohani. Ia mengaku bahwa Islam yang bersumber dari Al-Qur-an dan Al-Hadits, itulah yang memajukan berbagai ilmu. oleh karena itu pendidikan Islam harus berdasar dan tidak menyimpang dari sumber Islam tersebut.

\section{b. Pendidikan harus berdasar kebangsaan (Nasionalis)}

Menurut HOS Tjokroaminoto adalah untuk menjadikan anak didik sebagai seorang muslim sejati dan sekaligus menjadi seorang nasionalais hendaknya mempunyai keseimbangan baik ilmu umum maupun ilmu agama yang berjiwa besar penuh kepercayaan kepada diri sendiri.

c. Pendidikan Islam harus mempunyai akal yang cerdas dan budi.

Maka disamping itu akal yang cerdas juga harus mempunyai budi pekerti yang utama, hidup sederhana punya keberanian dan mendirian, cinta tanah air, mempertebal perasaan kebangsaan, bukan sebaliknya mengagungkan budaya asing.Berkaitan dengan maslah tersebut harus ada lembaga Pendidikan Islam yang mengelola pendidikan kebangsaan baik secara informal maupun non formah.pendidikan tersebut harus bertujuan mengangkat derajat dan martabat kemanusiaan dari setiap individu manusia.

\footnotetext{
${ }^{14}$ Sugiyono.2010, Metode Penelitian Kuantitatif Kualitatif, Bandung, Kencana, 225
} 


\section{d. Pendidikan Islam berdasarkan Cinta tanah air.}

Cinta tanah air yaitu sekuat tenaga mengadakan pendidikan untuk menanamkan perasaan kebangsaan, memiliki keberanian yaitu selalu menanamkan rasa keberanian terutama jihad (bekerja keras mempropagandakan dan melindungi Islam), karena hal itu termasuk bagian dari iman dan taqwa dan menanamkan difat kemandirian, maksudnya setiap orang harus berusaha dengan sungguh-sunggu dan pantang memakan hasil pekerjaan orang lain dan mampu mandiri tidak menggantungkan kepada orang lain. ${ }^{15}$

\section{Pembelajaran Pendidikan Islam}

\section{a. Pendidikan Keluarga}

Sesuai dengan nilai-nilai karakter.Ketaqwaan terhadap Tuhan Yang Maha Esa diharapkan memberikan pengaruh yang positif bagi mentalitas seroang anak dalam pendidikan keluarga.Pendidikan Islam yang diajarkanTjokroaminoto nampak diserap dengan baik oleh anak-anak kostnya dan tertanam dalam pemikiran sertamempengaruhi tindakan anak-anak kost.Pemahaman mengenai Islam turut mewarnai pemikiran dan tindakan anak-anak kost Tjokroaminoto yang kemudian juga memberikan warna pada aktivitas dalam organisasi maupun tulisan di berbagai penerbitan dan pidato.Pengajaran Islam oleh Tjokroaminoto, beserta diskusi yang dilakukan bersama tokoh-tokoh Islam, turut memberikan pengaruh dalam diri Soekarno.Kecenderungan Soekarno untuk lebih dekat dengan Islam merupakan sebuah konsekuensi logis dari pendidikan yang didapatkannya. ${ }^{16}$

Tjokroaminoto memang memilih jalan dialog dan memberikan ruang bagi tampilnya sejumlah individu yang beragam latar belakang, sehingga terjadi komunikasi dialog pada berbagai kesempatan dan tempat. Gonggong menambahkan bahwa hal ini sejalan dengan cara Tjokroaminoto mengelola rumahnya sendiri.

b. Menanamkan Benih Keberanian, keikhlasan, kesetiaan dan kecintaan kepada yang benar (Haq)

Tjokroaminoto memberikan pelajaran baik pada anaknya dan anak kosnya tentang arti kemerdekaan dan demokrasi yakni membela kebenaran dan berpihak pada rakyat serta hanya takut pada Allah SWT. Suatu ketika pernah anaknya yang baru lulus sekolah memberikan ijazah kelulusannya pada sang ayah tetapi bukan bangga atau senang, Tjokroaminoto kemudian dengan tegas malah merobeknya berkali-kali dan menegaskan pada anaknya bahwa lebih baik untuk menjadi abdi

\footnotetext{
${ }^{15}$ M. Masyhur Amin, 1995,H.O.S Tjokroaminoto: Rekonstruksi Pemikiran dan Perjuangannya, Yogyakarta: Cokroaminoto University Press, 29.

${ }^{16}$ Salam, S. 1982. Bung Karno Putera Fajar. Jakarta, Gunung Agung,158-164
} 
rakyat dengan membangun cabang SI. Anak kos Tjokroaminotopun pernah merasakan arti demokrasi yakni ketika Tjokroaminoto sedang berdiskusi dengan teman-temannya, mereka sering berbeda pendapat dalam memutuskan sesuatu sehingga kemudian diambil jalan tengahnya. Para anak kosnya ini biasanya hanya duduk mendengarkan dan mengamati saja. Tjokroaminoto memahami pentingnya rapat umum dan keberanian bicara buat menggalang massa. Di meja makan rumah Gang Peneleh, ilmu pergerakan modern ditularkan pada Alimin, Moeso, Sukarno, dan Kartosoewirjo. ${ }^{17}$

\section{c. Menanamkan Pendidikan Akhlak}

Hasil gagasannya yang ketiga dan keempat ialah menanamkan benih peri kebatinan yang halus, keutamaan budi pekerti dan kebaikan perangai, dan kehidupan yang saleh, yang dulu telah menyebabkan orang Arab penduduk laut pasir itu menjadi bangsa tuan yang halus adat lembaganya dan menjadi penanam dan penyebar keadaban dan kesopanan. Tjokroaminoto dengan segala tulisannya menggambarkan bagaimana seseorang harus berperilaku setidaknya setiap muslim harus menjadi muslim yang seutuhnya yang merasuk hingga rasa dan jiwanya. Hal ini tergambar jelas pada silabus dan kurikulum yang terjabarkan pada sekolah Tjokroaminoto di setiap cabang Syarikat Islam (SI).

\section{d. Menanamkan Benih kecintaan terhadap Tanah air}

Gagasannya yang terakhir ialah menanamkan rasa kecintaan terhadap tanah tumpah darah dengan jalan mempelajari kultur dan adat istiadat bangsa sendiri. Tjokroaminoto seringkali dalam satu atau dua minggu sekali mengadakan latihan wayang orang bertempat ditempat seni Panti Harsoyo bersama anakanaknya \& anak-anak pondokannya. Tjokro gemar bermain gamelan dan menari dan Istrinya suka bermain piano, hal ini menular pada anaknya. Salah seorang anaknya Harsono bukan hanya meneladani kegemaran orang tuanya tersebut tetapi meneladani semangat patriotisme, cinta tanah air, dan sifat kesederhanaan, dan gemar membantu sesamanya.

Harsono sering diajak dalam perjalanan ke desa-desa untuk menghadiri pertemuan-pertemuan Sarekat Islam. Awalnya Harsono tidak mengerti apa yang dilakukan ayahnya tetapi lama kelamaan ia mengerti apa yang dilakukan ayahnya tersebut dan secara otomatis tidak terasa timbul pula rasa kesadaran dalam batinnya; kesadaran cinta tanah air, kesadaran sebagai seorang muslim, kesadaran mengabdikan diri pada negara dan bangsa. Kesadaran untuk berkorban pada agama yang diyakini. Kesan terdalam Harsono pada ayahnya ketika ayahnya

\footnotetext{
${ }^{17}$ Tempo. 2011. Tjokroaminoto: Guru Para Pendiri Bangsa. Jakarta: Kepustakaan Populer Gramedia, 28
} 
dalam memberikan nasihat pada anak-anaknya tidak menggunakan kata-kata tetapi lebih diutamakan pada contoh serta perbuatan yang baik. ${ }^{18}$

\section{e. Mengaji Al-Quran Bagi Murid-muridnya}

Selain itu bagi Tjokroaminoto pendidikan Islam dilakukan pertama kali dengan mengaji Al-Qur-an untuk mendalami agama Islam, bukan hanya sekedar membaca disertai ilmu tajwidnya tetapi juga memaknai setiap ayat dalam kehidupan sehari-hari. Tjokroaminoto juga seringkali mengawasi kemajuan putera-puterinya dalam mengaji dan menunggu mereka hingga selesai mengaji. ${ }^{19}$

f. Menerapkan Uswatun Hasanah dan Handap Asor (Rendah hati)

Rumah Tjokroaminoto di Gang Peneleh Surabaya menjadi saksi bisu beberapa anak muda yang sedang menuntut ilmu dari seorang pemimpin SI. Banyak yang sekedar menyinggahi untuk berdialog tetapi ada juga yang tinggal bersamanya. Mengungkapkan muridnya antara lain adalah Soekarno, Kartosuwiryo, Abikoesno Tjokrosoejoso, Hamka, Alimin, dan Moeso. Dalam perkembangan nantinya mereka ini yang akan meneruskan perjuangan dalam membebaskan rakyat dari belenggu penjajahan dengan cara dan ideologi yang berbeda-beda. Soekarno dengan kampiun nasionalis, Semaoen dan Moeso memilih komunis serta Kartosuwiryo menjadi pemimpin umum fundamentalis Islam.

Sikap Tjokroaminoto yang memberikan keteladanan bagi murid-muridnya inilah yang banyak menjadi inspirasi bagi muridnya. Tjokroaminoto cenderung sering membawa serta salah satu murid kesayangannya yakni Soekarno ketika dia sedang berpidato di depan umat Sarekat Islam (SI) yang sangat besar jumlahnya. Daras (2011:29) menggambarkan bagaimana seorang Soekarno sering belajar berpidato di depan kaca di dalam kamar yang pengap dan gelap. Di salah satu kamar kost milik Tjokroaminoto tersebut Soekarno berpidato secara berapi-api. Bagi orang yang pernah melihat gaya berpidato Tjokroaminoto selalu mengungkapkan bahwa gaya serta cara berpidato Soekarno mirip dengan Tjokroaminoto. Tinggi rendahnya suara, cara mengatur kalimat, dan menyusun kata, sangat menarik dan gampang dipahami oleh segenap pendengarnya, tidak peduli apakah dia orang awam, terpelajar, sarjana, tukang becak atau pedagang (Soebagijo, 1985:8). Selain itu beberapa murid Tjokroaminoto ternyata juga memiliki kemampuan yang luar biasa dalam berpidato yang mempengaruhi massanya seperti Semaoen dan Moeso. Prasetyo (2008:198)

Soebagijo (1985:10) menjelaskan sikap andap asor (rendah hati) Bung Karno diteladani dari Tjokro selain pemimpin umat yang tergabung dalam sarekat islam, singa mimbar, ahli pidato, orator ulung, juga dikenal sebagai seorang yang

\footnotetext{
${ }^{18}$ Soebagijo. 1985. Harsono TjokroaminotoMengikuti Jejak Perjuangan Sang Ayah. Jakarta, Gunung Agung, 11-12

${ }^{19}$ Ibid, 6
} 
rendah hati, berendah hati, suka menolong, gemar berkorban untuk sesama. Soekarno merupakan anak emas Tjokro di rumah Gang Peneleh hampir setiap malam usai makan di saat banyak anak kos seusianya menonton televisi, dia duduk bersimpuh di dekat kaki Tjokro dan mendengarkan semua hal yang dilakukan Tjokro yang berakhir Tjokro memberikan banyak bukunya pada Soekarno (hal ini pula yang dilakukan oleh Semaoen walaupun akhirnya ia mengkritik tindakan sang mentor).

\section{E. Simpulan}

Berdasarkan hasil penelitian tentang Perspektif HOS Tjokroaminoto tentang Pendidikan Islam dapat disimpulkan bahwa: Selain keilmuan formal yang menjadi standar-standar sekolah Belanda atau Pribumi, Pak Tjokro memberikan enam penekanan yang penting dalam pembentukan manusia melalui pendidikan Islam selain memberikan kepandaian legal yaitu: a). Pendidikan Islam harus berdasarkan Al-Qur-an. b). Menanamkan benih kemerdekaan dan benih demokrasi. c). Anak didik harus di tanamkan benih keberanian, keihlasan hati, kesetiaan dan kecintaan pada yang benar (haq). d). Menanamkan benih Pri kebatinan (Ruh/Spiritual) yang halus, benih keutamaan budi dan perangai yang benar. e). Menanamkan benih kehidupan yang saleh dan sederhana. f). Pengkajian dalam Al-Quran secara rutin.

Dari pemikiran-pemikiran Pak Tjokro tentang pendidikan di atas, patut kita teladani dan contoh sebagai bahan refrensi untuk mengajar pada anak-anak didik kita.Pendidikan karakter adalah pendidikan yang harus di miliki setiap anak Indonesia.Karena dewasa ini, semakin hari semakin tak terkendalikan fitnah-fitnah bertebaran di media sosial, demi kepentingan politik, demi kekuasaan dan demi kelompoknya masing-masing. Orang yang tidak tahu, orang tidak bisa membaca situasi akan cepat terpengaruhi dengan keadaan yang penuh dengan fitnah ini. Ikut-ikutan menyebarkan berita-berita yang belum tentu kebenarannya.

\section{Daftar Pustaka}

Ahmad, H, 2010, Ekonomi dalam Pandangan HOS Tjokroaminoto. Diakses tanggal 12 Juni 2012 dari http://harisahmad.blogspot.com/2010/05/ekonomidalampandangan-hos.html

Amels, 1952, H.O.S Tjokroaminoto Jilid 1, Djakarta, Bulan Bintang

Lexy J. Moleong, 2005, Metodologi Penelitian kualitatif, Bandung, Remaja Rosdakarya Manpan Drajat, M. R. E. (2015). Etika Ptrofesi Guru. Alfabeta.

Effendi, M. Ridwan dan Manpan Drajat. Etika Profesi Guru. Cet. I: Bandung; Alfabeta, 2014. Muljono \& S. Kutoyo,1985, Haji Saman Hudi, Jakarta, Depdikbud

Mukti, D. 2010. Tjokroaminoto dan PendidikanMoeslim Nationaal, Onderwijs, Diakses tanggal 17 Juni 2012, dari http:/tjokroaminoto, wordpress.com/ Onderwijs

M. Masyhur Amin, 1995,H.O.S Tjokroaminoto: Rekonstruksi Pemikiran dan Perjuangannya, Yogyakarta, Cokroaminoto University Press 
Scherer, SP, 1985, Keselarasan \& KejanggalanPemikiran-Pemikiran Priayi Nasionalis Jawa Awal Abad XX, Jakarta, Sinar Harapan

Soebagijo, 1985, Harsono TjokroaminotoMengikuti Jejak Perjuangan Sang Ayah, Jakarta, Gunung Agung

Syahrin Harahap, 2011, Metodologi Studi Tokoh Pemikiran Islam, Jakarta, Prenada

Sugiyono. 2010, Metode Penelitian Kuantitatif Kualitatif, Bandung, Kencana

Salam, S. 1982. Bung Karno Putera Fajar. Jakarta, Gunung Agung

Tjokroaminoto, H. 1983, Menelusuri Jejak Ayahku, Penerbitan Sejarah Lisan No. 2. Jakarta, Arsip Nasional Republik Indonesia

Tempo. 2011, TjokroaminotoGuru Para Pendiri Bangsa, Jakarta, Kepustakaan Populer Gramedia 